\title{
INDUSTRI PERTENUNAN ATBM DI KAB. WAJO ( Suatu Studi mengenai Kehidupan Sosial Keagamaan Masyarakat Pengrajin )
}

\section{OLEH : ABD. KADIR MASSOWEANG}

I

Kabupaten Wajo merupakan suatu daerah yang sudah terkenal sebagai penghasil pertenunan, baik berupa sarung, selendang, bahan baju dan lain-lain. Pertenunan dengan Alat Tenun Bukan Mesin (ATBM) adalah suatu potensi usaha yang memberikan sumbangan besar kepada pemerintah dalam bidang pembangunan. Pelaksanaan pembangunan yang saat ini memasuki tahun pertama Pelita ke Lima semakin merata sampai ke pelosok pelosok desa. Masyarakat yang menghuni daerah pedesaan dan pinggiran pinggiran kota tidak terlepas dari sasaran pembangunan.

Pemerintah Orde Baru sejak awal Pelita dan dalam Pelita lima memberikan perhatian yang besar dalam pembinaan dan pengembangan industri kecil, termasuk industri sandang (pertenunan ATBM) dengan terus memberikan bimbingan teknis, bimbingan organisasi dan managemen, pembinaan wiraswasta, pemberian kredit dan latihan, bantuan peralatan dan bahan baku, bantuan tenaga ahli dan sebagainya, dalam upaya peningkatan tarap hidup pengusaha kecil dan pengrajin, memperluas lapangan kerja dan kesempatan berusaha serta meningkatkan ekspor, khususnya ekspor non migas.

Namun demikian, kenyataan yang terlihat dalam masyarakat, bahwa masih sebahagian pengrajin, khususnya pengrajin pekerja yang masih hidup serba kekurangan, penghasilannya relatif kecil bila dibanding dengan kebu- tuhan hidupnya, Lain halnya dengan pengrajin pengusaha yang mempunyai kesempatan untuk memperoleh keuntungan, sehingga nampaknya terjadi kesenjangan antara kedua kelompok pengrajin itu, terutama nampak dalam kehidupan sosial ekonomi masyarakat.

Tinggi rendahnya pendapatan dan kesejahteraan hidup dapat mempengaruhi pola pikir dan pola pandang yang tercermin dalam sikap dan tingkah laku seseorang yang pada giliran selanjutnya berpengaruh pada pola kehidupan masyarakat. Oleh karena itu penelitian ini mengamati kehidupan sosial keagamaan masyarakat pengrajin pertenunan ATBM di Kabupaten Wajo.

Lokasi penelitian ini di desa Pakkanna kecamatan Tanasitolo Kabupaten Wajo. Dipilihnya desa ini sebagai lokasi penelitian, karena disamping memiliki banyak pengrajin, ia merupakan tempat dimulainya dan pusat pengembangan industri pertenunan ATBM di Kabupaten Wajo. Dalam pengumpulan data menggunakan wawancara mendalam dengan para informan, observasi langsung di lokasi penelitian dan penelusuran terhadap literatur dan dokumentasi. Analisis data dilakukan secara kualitatif dengan memperhatikan kategori-kategori, jenis data dan tujuan penelitian.

\section{II}

Desa Pakkanna merupakan salah satu desa diantara 7 desa yang terdapat dalam wilayah pemerintahan Kecamatan Tanasitolo. Letaknya berada di garis perbatasan Kecamatan Tana- 
sitolo bahagian selatan dengan kecamatan Tempe, Di sebelah timur berbatasan dengan desa Nepo Kecamatan Tanasitolo dan di bahagian barat berbatasan dengan danau Tempe.

Penduduk desa Pakkanna berjumlah 5248 jiwa, terdiri dari pria sebanyak 2473 orang dan wanita sebanyak 2775 orang. Jika dibandingkan jumlah penduduk dengan luas wilayah desa ini 8,96 kilometer persegi. Maka pendapatan kepadatan penduduk rata-rata 586 jiwa perkilometer persegi. Angka ini lebih dua kali lipat dari angka rata-rata kepadatan penduduk se kecamatan Tanasitolo yang hanya mencapai 248 jiwa perkilometer persegi. Semua penduduk di desa ini adalah pemeluk agama Islam. Dilihatdari klfisikasi umur 1363 jiwa berumur dibawah 10-55 tahun yang merupakan angkatan kerja potensial berjumlah 3293 jiwa dan 642 jiwa berumur 55 tahun keatas.

Mengenai kwalitas penduduk desa ini dilihat dari segi pendidikan sangat memperhatinkan. Data di kantor Desa menyatakan bahwa penduduk yang tidak pernah sekolah dan tidak tamat SD sebanyak 3714 orang (71\%), tamat SD 1143 orang, tamat SMTP 258 orang, tamat SMTA 122 orang dan Sarjana Muda 11 orang. Sedang anak-anak usia sekolah (7-12) cukup , menggembirakan, ka-rena dari jumlah anak usia sekolah 649 orang, yang sekolah 626 orang dan yang tidak dan belum sekolah hanya 23 orang anak.

Ada 4 mata pencaharian penduduk yang menonjol di desa ini yaitu, pengusaha ATBM (pengrajin) 1397 orang. Petani 420 orang, Pedagang 353 orang dan nelayan 327 orang.

Penduduk menyebar di 2 dusun yaitu dusun Impa-Impa dan Empagae. Rumah rumah penduduk yang berjumalh 1011 buah di bangun dalam bentuk rumah panggung berkaki kayu setinggi 2 meter berdinding papan atau bambu dan beratapkan seng atau daun nipa. Pada umumnya kolong rumah penduduk diberi dinding papan atau bambu sebagai tempat pertenunan ATBM. Setiap rumah memiliki antara satu sampai sepuluh unit ATBM. keadaan alamnya berupa dataran rendah, karena berada di pesisir danau Tempe, sehingga bila air danau meluap sebahagian rumah penduduk akan teremdam air, terutama disebelah barat jalan raya yang arealnya agak berbukit.

Sarana kesehatan yang ada yaitu satu puskesmas, 2 buah Pos KB, 2 buah Posyandu, Kamar mandi 5 buah, 745 WC, Sumur Pompa 278 dan sumur biasa 239 buah. Sarana pendidikan terdiri dari 2 buah gedung SD. Sarana keagamaan 2 buah masjid dan sarana ekonomi terdiri dari 1 kelompok pertokoan dan 1 buah pasar umum yang terkenal dengan nama "pasar Sempangnge" karena terletak didekat persim-pangan jalan.

Semua penduduk di desa ini terdiri dari orang bugis, sehingga sistem kekerabatannya menganut sistem kekerabatan bilateral dan bahasa yang di pergunakan penduduk seharihari adalah bahasa Bugis.

\section{IIl}

Pertenunan ATBM ini dikenal di desa ini pada tahun 1953. Alat ini didatangkan oleh pedagang antar pulau yang bernama Haji Ibrahim Dg. Manrapi dari Gresik (pulau Jawa). Sebelum dikenalnya ATBM ini, pertenunan di lakukan dengan peralatan tradisional (pertenu nan gedongan) dimana produksinya hanya terbatas pada sarung sutera saja.

Pengembangan pertenunan ini pada mulanya hanya terbatas pada lingkungan keluarga dan tetangga terdekat Dg. Manrapi saja, sejak tahun 1970 setelah pemerintah memberikan

No. 1 \& 2 Thn. I Juli / Desember 1990 
bantuan teknis maupun bantuan bahan baku yang terjangkau daya beli masyarakat, pertenunan ini berkembang sampai di luar kecamatan Tanasitolo dalam wilayah kabupaten Wajo. Data tahun 1988 menunjukkan bahwa jumlah unit usaha ATBM di Kabupaten Wajo 1935 unit dan peralatan 5500 buah ATBM.

Dari 1937 pengrajin di desa Pakkanna dapat di kelompokkan menjadi 2 yaitu kelompok pengrajin pekerja dan kelompok pengrajin pengusaha. Pengrajin pekerja adalah tenaga harian para pengusaha yang melakukan proses pekerjaan pertenuan mulai dari proses pengolahan bahan baku menjadi bahan yang siap di tenun sampai kepada hasil produksi. Proses pengolahan bahan baku menjadi bahan yang siap di tenun dilakukan oleh tenaga kerja pria maupun wanita, sedangkan proses pertenunan sampai kepada hasil produksi seluruhnya dikerjakan oleh tenaga kerja wanita. Pengrajin pengusaha adalah pemilik modal dan perala$\tan (\mathrm{ATBM}$ ) asetiap pengrajin ini memiliki peralatan (ATBM) antara 1 sampai 70 ATBM, tergantung kepada modal yang mereka miliki.

Bahan baku pertenunan ATBM di desa Pakkanna terdiri dari benang sutera, benang mesres dan benang spunsilk. Hingga dewasa ini, kebanyakan pengrajin pengusaha menggunakan bahan baku benang mesres, karena disamping harganya murah, pengolahannya tidak memakan waktu yang lama. Benang spunsilk pengolahannya sama dengan mesres, tapi harganya terlalu mahal. Sedangkan benang sutera, meskipun harganya tidak terlalu mahal, tetapi pengolahannya memerlukan waktu yang lama dan keahlian yang tersendiri. Pada waktu penelitian ini dilakukan harga bahan baku perpak di pasar yaitu: benang spunsilk Rp.600.000,-, sutera Rp. 150.000,- dan mesres Rp.40.000,--

No. 1 \& 2 Thn. I Juli / Desember 1990
Pada umumnya pengrajin pengusaha adalah golongan ekonomi lemah, modal yang dimiliki hanya untuk pengadaan ATBM dan penyediaan bahan baku serta bahan penunjang lainya. Pengrajin yang hanya memiliki ATBM saja, dapat di berika modal bahan baku oleh para pedagang (tengkulak ) dengan harga di atas harga pasar. Mengenai upah tenaga kerja tidaklah menjadi masalah, karena pengrajin yang hanya memiliki 1 atau 2 alat ATBM, ia sendiri yang mengerjakannya atau mempergunakan anggota keluarga. Dari hasil keungtungan penjualan digunakan untuk penyediaan bahan baku untuk proses produksi selanjutnya, sedangkan selebihnya dari keuntungan tersebut dimanfaatkan untuk kebutuhan keluarga.

Melihat produksi pertenunan ATBM- di desa Pakkanna sangat di tentukan oleh kemampuan modal dan kwalitas bahan baku. Produksi pertenunan terdiri dari: Sarung spunsilk, sarung mesres, sarung sutera, kain sutera dan selendang. Pemasaran produksi pertenunan ini dilakukan oleh para pengrajin dengan berbagai cara yaitu : pengrajin yang langsung membawa ke pasar "Sempangnge" dan menjualnya kepada pembeli borongan (pedagang) atau pembeli eceran, ataukah pedagang dan pembeli eceran yang mendatangi rumah pengrajin. Kelemahan di bidang pemasaran disebabkan karena terjadinya persaingan harga akibat kwalitas produksi dan masuknya produksi dari luar yang bersaing harga dan kwalitas terutama sarung mesres.

\section{IV}

Penduduk desa Pakkanna seluruhnya beragama Islam. Pengetahuan keagamaan yang mereka miliki cukup memberikan dorongan dalam melakukan aktifitas keagamaan, baik dalam bentuk ibadah maupun dalam bentuk 
upacara-upacara keagamaan. Ibadah shalat sebagai kewajiban setiap muslim mereka melakukannya di rumah atau di mesjid. Bagi mereka yang rumahnya berjauhan dengan masjid dilakukannya di rumah baik secara berjamaah bersama seluruh keluarga maupun sendirian. Diantara mereka ada orang yang rajin melakukan shalat berjamaah di masjid terutama yang berdekatan rumahnya dengan masjid.

Ada 2 masjid di desa ini, satu di dusun Empagae dan satu di dusun Impa-Impa. Masjid yang ada di Impa-Impa lebih besar dan lebih bagus daripada yang ada di Empagae. Hal ini dapat dipahami karena para pengrajin pengusaha bertempat tinggal di Impa-Impa, sedangkan di Empagae pada umumnya pengrajin pekerja. Dana yang di pergunakan untuk pembangunan masjid ini adalah swadaya masyarakat. Kegiatan pokok di masjid ini ialah shalat jamaah lima waktu dan shalat jum'at disamping itu shalat hari raya juga dilakukan di masjid, karena lebih afdol daripada di lapangan.

Upacara keagamaan yang berkaitan dengan hari-hari besar Islam seperti maulid dan isra mi'raj dilaksanakan di masjid secara meriah dengan mendatangkan ulama yang terkenal, baik di dalam kabupaten Wajo maupun dari luar. Khusus untuk acara maulid masyarakat menyediakan hidangan khusus berupa nasi ketan dan telur yang disimpan dalam suatu tempat, lalu di bawa ke masjid, sedang peringatan isra mi'raj, mereka hanya menyediakan kue sesuai dengan keinginannya. Ada juga beberapa keluarga (11 rumah) yang selalu melaksanakan kedua acara ini dirumahnya dengan memanggil guru syara'membacakan maulid dan mi'raj nabi. Mereka kadang-kadang memotong kambing atau kerbau dimakan bersama-sama dengan seluruh keluarga dan tetangga serta undangan. Hal itu mereka lakukan setiap bulan maulid atau bulan rajab.

Suasana bulan Ramadhan dalam melakukan puasa sangat terasa pada kehidupan masyarakat, namun demikian puasa tidak mempengaruhi mereka dalam melakukan kegiatannya sebagai pengrajin. Sebahagian besar mereka menghentikan kegiatannya satu minggu sebelum lebaran dalam rangka mempersiapkan diri untuk hari raya Idul Fitri. Zakat fitrah, juga merupakan perhatian masyarakat menjelang hari raya Idul Fitri.

Menunaikan ibadah haji, menjadi dambaan masyarakat untuk menyempurnakan pelaksanaan rukun Islam. Oleh karena ibadah ini memerlukan dana yang banyak, sehingga hanya pengrajin pengusaha yang mampu melakukannya, sedangkan pengrajin pekerja dengan mengharap dari upah kerja sulit untuk melakukannya. Sejak berkembangnya pertenunan ATBM di desa ini, maka delapan tahun terakhir ini rata-rata yang menunaikan ibadah haji dari pengrajin pengusaha 5 orang setiap tahun.

Masyarakat Pengrajin di desa Pakkanna tidak memiliki upacara-upacara tertentu dalam melakukan usahanya, seperti yang didapati dalam masyarakat petani dan nelayan. Upacara yang mereka lakukan adalah upacara siklus hidup seperti kelahiran, khitanan, perkawinan dan syukuran atas sesuatu keberhasilan. Ada kebiasaan masyarakat di desa ini apabila melakukan acara aqiqah, khitanan dan syukuran para tetangga dan famili membawakan bantuan dalam bentuk barang konsumsi, seperti gula, teh dan sebagainya. Apabila barang tersebut dibawa dalam suatu wadah, maka sebelum wadah itu dikembalikan kepada pembawanya, terlebih dahulu diisi dengan kue oleh tuan rumah. Hal ini dilakukan sebagai 
tanda terima kasih atas pemberiannya.

Setiap upacara siklus hidup dan acara syukuran selalu disertai dengan pembacaan berzanji, yang dibacakan oleh para pegawai syara' dan undangan yang tahu membacanya. Disamping itu acara baca berzanji dilakukan setiap bulan Sya'ban dan setiap malam jum'at di rumah orang yang sedang menunaikan ibadah haji di Mekah.

Perhatian masyarakat terhadap pendidikan agama anak-anak mereka sangat besar, terutama pendidikan pengajian Al Qur'an. Mereka mengirim anaknya belajar mengaji ke rumahrumah guru mengaji. Hampir tidak ditemukan orang yang mengajar anaknya mengaji Al Qur'an. Tempat mengaji Al Qur'an (mengaji akorang) tersebar di dua dusun di desa Pakkanna. Jumlah tempat mengaji 10 buah, 3 buah di dusun Empagae dan 7 buah di dusun Impa-Impa. Jumlah murid yang mengaji bagi setiap tempat antara 7 sampai 27 orang. Waktu belajar mengaji adalah waktu sore, karena mereka sekolah waktu pagi.

Ada beberapa keluarga yang mengirim anaknya ke madrasah As'adiyah di Sengkang, setelah menamatkan pelajarannya di sekolah dasar untuk memperdalam ilmu agama. Jarak antara Sengkang dengan desa ini hanya $5 \mathrm{~km}$. dan alat transportasi lancar setiap hari dengan kendaraan umum mikrolet.

Kerukunan hidup ummat beragama dalam masyarakat di desa ini cukup mantap. $\mathrm{Hu}-$ bungan intern umat Islam berjalan dengan baik, disebabkan karena semua anggota kelompok keagamaan yang ada* menghindarkan diri mempermasalahkan masalah khilafiah. Kemudian hubungan antar umat Islam dengan pemerintah berjalan baik juga, karena antara kedua belah pihak mempunyai kepentingan yang sama di dalam memajukan dan mengembangkan industri pertenunan ATBM.

\section{DAFTAR KEPUSTAKAAN}

\author{
Abdullah, Taufik : Agama, Etos Kerja dan \\ Perkembangan Ekonomi, \\ Jakarta, LP3ES, 1979 \\ Kantor Departemen Perindustrian Kabupaten \\ Wajo : Laporan Tahunan Indus- \\ tri, 1988 \\ Koentjaraningrat : Kebudayaan, Men- talitet \\ dan Pembangunan, Jakrta, Gra- \\ media, 1982
}

\author{
: Metode-Metode Penelitian \\ Masyarakat, Jakarta, Gramedia, \\ 1985 \\ Kantor Statistik Kabupaten Wajo : Kabupaten \\ Wajo dalam Angka 1987. \\ Mukhlis (Ed) : Dinamika Bugis Makassar, \\ PLPIIS-YIIS, 1986. \\ Mukhlis dan Kathryn Robinson (Ed.): Agama \\ dan Realitas Sosial, Ujung \\ Pandang, Lephas, 1985
}

